Volume 11 Number 3, July-September 2017: pp. 289-301. Copyright (C) 2017 FIAT JUSTISIA. Faculty of Law, Lampung University, Bandarlampung, Lampung, Indonesia. ISSN: 1978-5186 | e-ISSN: 2477-6238.

Open Access: http://jurnal.fh.unila.ac.id/index.php/fiat

Fiat Justisia is licensed under a Creative Commons Attribution 4.0 International License, which permits unrestricted use, distribution, and reproduction in any medium, provided the original work is properly cited.
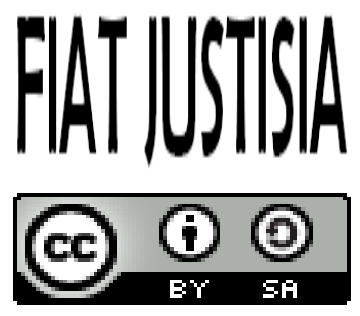

\title{
The Development of Legal Education in the Kingdom of Saudi Arabia
}

\author{
Muamar Hasan Salameh \\ Department of Law, Prince Mohammad Bin Fahd University, \\ Akhobar, Saudi Arabia \\ msalameh@pmu.edu.sa \\ Jaida Aboul Fotouh \\ Department of Law, Prince Mohammad in Fahd University, \\ Akhobar, Saudi Arabia \\ jaida_af@aucegypt.edu
}

\begin{abstract}
In the Kingdom of Saudi Arabia (KSA), Islamic Shariah is the foundation of the laws of the state. While the modern Saudi legal system encompasses both written and unwritten laws, Shariah is still considered supreme and hence directs most of the state's regulations. Nevertheless, currently, those who aim to practice law need to acquire a foundation of all prevailing laws. Due to the supremacy of Shariah, most universities still do not offer comprehensive degree plans, which often poses limitations to the development of legal education in the Kingdom. This study aims to address this conundrum by examining the various degree plans in Saudi universities, scrutinizing whether they offer comprehensive degrees, which should encompass both Shariah laws yet also the newly codified rules. This research draws upon secondary sources, which analyze the progress of the legal education in KSA and its effects on future legal practitioners. Results suggest that the legal curricular should be redesigned to improve the capabilities of prospective legal professionals by integrating the noncodified rules of law with the Islamic law in a more practical, realistic and efficient manner.
\end{abstract}

Keywords: Legal education, Shariah, Saudi Arabia. 


\section{A. Introduction}

Saudi Arabia has witnessed tremendous progress in the field of legal education. This change has occurred as a result of recent developments in the legal system of the Kingdom, which includes the codification of various rules in administrative, criminal, and commercial areas. The law in Saudi Arabia can primarily be described as consolidation of both written and unwritten laws. While the fundamentals of Sharia are the main source of state laws, regulations as well as court decisions, the Kingdom is now incorporating a modern system of litigation. Since the codification of modern laws has only recently gained widespread recognition among the authorities, this has raised an urgent demand for legal professionals, who can employ their skills to pace-up the process. Expansion in the scope of legal codification has encouraged different Arabian universities to offer courses in the respective realm and therefore have introduced bachelor degrees.

Notwithstanding, the international advancement and expansion of legal education pose significant challenges to KSA, which is why the legal education cannot be embraced the way it is required. It has significantly halted the progress and made it difficult to pursue the change. It emphasizes the need for conducting empirical researchers to direct the development of legal education in KSA, the way it has successfully emerged in other countries.

This research aims to assess the development of procedures conducted in Saudi Arabia regarding the legal education system and the possible routes of offering courses that integrate the supreme unwritten Shariah law into the newly codified law. Assessing the findings pertaining the study of law and Shariah, there have been some studies conducted that provide insight to the development of legal education in the KSA; however, only a few of these have taken into account the effect of Shariah law on the newly codified laws. A working paper presented in 2011 at the Prince Sultan University highlights the need for revising the legal education paradigms in KSA. ${ }^{1}$ Dr. Ayoub Algarbough asserts in his paper that the system of legal education must be structured in a way that graduates must have comprehensive knowledge of Shariah law. The solution that the author has proposed for this change is to extend the duration of the degree and introduction of a foundation year (i.e., a five years bachelor degree). This will allow the undergraduates to gain sufficient knowledge of Shariah and would be able to understand its validity for the different decisions and regulations the state issues in different instances. The graduates would consequently be able to work in all the fields of legal practice including the

\footnotetext{
${ }^{1}$ A. Algarbouh, "The assessment of legal education in the Kingdom of Saudi Arabia", Proceedings of the Education and Learning Conference, Prince Sultan University, (2011)
} 
judiciary. Moreover, the universities will be able to offer effective courses in Islamic law.

Another author examining the legal education in KSA is Rayan Alkhalwai, who proposed some significant alternations to the legal education in Saudi Arabia. The study critically analyzed the efficiency of the current plan; the Taibah University offers to undergraduates and the opportunities available to the legal market. ${ }^{2}$ Data was collected based on curriculum review, examining its comprehensiveness and adequacy to meet the advanced standards of legal education. The study identifies the current curriculum as inappropriate regarding the admission and selection criteria, the background of professors, as well as the overall environment. The author concludes that the current curriculum does not allow graduates to gain success with the prospective legal frameworks. The curriculum must be revised since it does not follow the realistic market perspectives applied in KSA. Professors responsible for rendering knowledge are hired from different backgrounds, and the assessments they undergo are only weaker. The study identified a significant lack of qualifications and skills among the high school students joining the Taibah University aiming to major in law.

While the studies mentioned above examine the legal education in KSA, the contemporary advancement of the study of law constitutes a sensitive issue because the current modernization of laws is considered as abandonment or drift to the Islamic laws. It remains the particular reason why the matter is only sparsely documented and is acquiring lesser support. ${ }^{3}$ The issue is mostly documented on websites, social media platform, and online newspapers. Proponents of the legal education development and advancement often are criticized for their beliefs; they are accused of not believing in the power of Shariah law. ${ }^{45}$

The research aims to analyze the significance of the legal field in KSA and how the system embraces the importance of Shariah law. It mainly addresses the problem of how law students often face confusion about the relation between the Islamic provisions and the newly codified laws. Moreover, the research will examine how future judges may obtain a certificate in Shariah law and how the degree in law or Shariah may help the prospective lawyers. The research mainly addresses the question of how the

\footnotetext{
${ }^{2}$ R. Alkhalawi, Legal Education Reform in Saudi Arabia: A Case Study of Taibah University, $\mathrm{PhD}$ dissertation, Maurer School of Law, Indiana University, (2015).

${ }^{3}$ L. Sossin, "Experience the Future of Legal Education", Alberta Law Review, 51 (2013), p.849.

${ }^{4}$ M. R. Grosu, "The Role of Innovative Teaching and Learning Methods in Legal Education", Proceedings of the International Conference- Future of Education, Budapest, (2011)

${ }^{5}$ R. A. Aldabas, "Special education in Saudi Arabia: History and Areas for Reform", Creative Education, 6 (11), (2015), p. 1158.
} 
supremacy of Sharia law constraints the development of legal education in Saudi Arabia and how the newly codified law should be integrated within the system to offer comprehensive degrees for future legal practitioners.

\section{B. Research Method}

The research will include an analysis of the legal education in KSA by examining the various codes, laws, and constitutions. The study will also assess the degree plans that various law institutions in KSA apply. The objectives of this study are first, the analysis of the Saudi legal systems and the guiding force of Sharia Law within the system; secondly, the examination of the judicial systems in KSA; thirdly, the analysis of the legal practice in KSA; fourthly, the evaluation of the structure of the legal education in KSA; and finally, the assessment of the curricular and degree plans that different legal institutions apply. Repercussions of a fragmented legal education system.

\section{Discussion}

\section{Legal System in the KSA}

The history of KSA's legal system can be traced back to 1932 when its constitution was first formulated. Ever since it was formed, the Islamic law reins the state's regulations across KSA. This principle was further validated in 1992 when the Basic Law of Governance was introduced. ${ }^{6}$ Article 7 of the given governance law provides that KSA draws its rule from the Holy Book (Quran) and Sunnah; both of these forms the guiding sources of the law in the Kingdom. ${ }^{7}$ Article 46 further asserts that while the judiciary must act as an independent authority, Islamic Shariah dictates its main functions and abilities. Furthermore, article 48 provides that the Islamic Shariah principles must be applied to all cases in the courts in accordance to Quran and Sunnah. Article 67 finally states that the regulatory authority may exercise no power in the promulgation of rules and laws that encourage the realization of the common good and prevent the state from harms, guided by the Shariah principles. ${ }^{8910}$ In 1992 a Royal Decree established the Shura Council which also validates a similar principle. Article 2 of the Decree

\footnotetext{
6 A. H. Al-Fahad, "Ornamental constitutionalism: The Saudi basic law of governance", Yale Journal of International Law, 30, (2005), p. 375.

${ }^{7}$ S.Heikal, "Lawyering in Arab Countries between the Hammer of the Executive and the Anvil of the Judiciary”, Journal of Studies in Social Sciences, 14 (2), (2016), p. 106.

${ }^{8}$ Ibid.

${ }^{9}$ M. Al Atawneh, "Is Saudi Arabia a theocracy? Religion and governance in contemporary Saudi Arabia”, Middle Eastern Studies, 45 (5), (2009), pp. 721-737.

10 J. Carver \& M. Carver, Basic principles of policy governance, San Francisco CA: JosseyBass, (1996).
} 
affirms that the council strictly adheres to the sources of Islamic legislation and that all members of the council must make deliberate efforts to bring the best in public interest and strengthen the bonds of unity among the communities across the nation. ${ }^{11}$

\section{Sources of Legislation in the Saudi Legal System}

As mentioned previously, article 48 emphasizes firstly that courts must apply Islamic provisions to all case hearings as Quran and Sunnah indicates, and secondly, the rules of law issued by the state must also conform to Quran and Sunnah. While provisions in the given article might seem clear at first instance, such a principle creates in many instances a conundrum to the judicial authority. ${ }^{12}$ Judges often face the challenge of whether they must decide solely according to the rules and the law of Shariah or they should consider the newly codified written laws. Consequently, to solve such a dilemma judges tend to ignore modern laws. It can better be understood by examining the Commercial Law, which undoubtedly forms the oldest written law in KSA. The Commercial Courts first disseminated the Law in 1970, attempting to modernize the rules and regulations governing commerce and business.

Nevertheless, the majority of judges refused to apply the positive laws mainly due to the belief that such laws are not Shariah but are man-made, and their application might breach the rules and regulations of their Islamic customary laws. ${ }^{1314}$

As a result, the state has established quasi-judicial committees, which are highly administrative. The purpose of these committees is to adjudicate the financial and commercial matters. ${ }^{1516}$ These committees are extremely important since they support dispute resolution processes by employing a competent and specialized team of members. Furthermore, they help to solve the issues that arise as a result of judiciary's failure/refusal to apply the codified laws because of fear of abandonment of the customary Shariah provisions. ${ }^{17}$ Examining the different newly codified laws applied in the

\footnotetext{
${ }^{11}$ A. Ehteshami "Reform From Above: The Politics of Participation in The Oil Monarchies", International Affairs, 79 (1), (2003), pp. 53-75.

${ }^{12}$ D. J. Karl, "Islamic Law in Saudi Arabia: What Foreign Attorney's Should Know", George Washington Journal of International Law and Economics, 25 (1991), p. 131.

${ }^{13}$ H. L. Stovall, "Arab Commercial Laws-Into the Future", The International Lawyer, 34 (3), (2000), pp. 839-847.

${ }^{14}$ Brand, J. L. "Aspects of Saudi Arabian Law and Practice", Boston College International and Comparative Law Review, 9 (1), (1986), p. 3

${ }^{15}$ D. J. Karl, Loc.Cit.

${ }^{16}$ A.A. Al-Ghadyan, "The Judiciary in Saudi Arabia", Arab Law Quarterly, 13 (3), (1998), pp. 235-251.

${ }^{17}$ Ibid.
} 
Kingdom, they include the Labor Law of 2004, the Judicial Code of 2006, the court proceedings of 2014, and the criminal procedures of 2014. However, it is important to note that most of these laws do not follow the legislative sources, with Labor Law as an exception. Article 223 of the law asserts that none of the organs of these institutions have the power to issue any codes, due to the lack of procedure or laws and therefore must draw upon the principles of Islamic law and rely either on the case law, the custom or the rules of justice. ${ }^{18}$ The article, nevertheless, fails to establish which hierarchy of sources must be followed and therefore allows the judiciary decides according to their discretion. Hence, to address such a perplexing situation, the Minister of Labor formed a body specifically dedicated to handling the labor disputes. This body is responsible for the adjudication instead of leaving the labor matters at the expense of the regular courts. ${ }^{19}$

In October 2017, the Minister of Justice, Chairman of the Supreme Judicial Council of Saudi Arabia, announced the commencement of commercial courts. The Saudi judicial system issued in 2007, provided for the establishment of specialized courts, including commercial courts, which would come to the effective implementation ten years after the issuance of the system. The initiation of commercial courts could be regarded as a step forward because with the presence of specialized commercial courts; there will be judges who would have comprehensive knowledge of both customary Islamic rules and modern laws. It will not just contribute to the development of law in the Kingdom and but might lead to easier and more efficient handling of trade disputes, which will certainly conduct to the reduction of quasi-judicial commissions in commercial disputes. Therefore one must stress that with such findings, it is important to note that the prospective legal professionals must be provided with adequate knowledge of laws and rules, so they are not only able to understand the Shariah laws and the codified positive laws, but may also retain a rightful complementary balance to make informed decision making where and when necessary.

\section{a. The judicial system in KSA}

The reform of the judicial system in KSA was contemplated through a new judiciary system that was developed in 2007 and replaced the old judiciary system of 1975 . The development of a two-tier litigation system was one of the most notable advancements, which was implemented by the Supreme Court of Justice. Article 9 affirms that the competent courts in the Kingdom will consist of the following: the Supreme Court, Courts of Appeals and First Instance Courts, which will encompass general courts,

${ }^{18}$ D. J. Karl, Loc.Cit.

${ }^{19}$ F. E.Vogel, Islamic Law and the Legal System of Saudí: Studies of Saudi Arabia, Brill, (2000), p. 288. 
penal courts, family courts, commercial courts and finally labor courts. Such courts will have jurisdiction over matters, where Sharia Law and the law of criminal procedures apply. Moreover, upon the approval of the King, the Supreme Judicial Council may establish other specialized courts.

In terms of qualification of judges, the candidate must fulfill the following requirements for his appointment: Saudi nationality by descent is required; he must have good character and conduct; he shall be fully competent to hold the position of a judge by Shariah; a degree in Shariah is required or any other degree that certifies the passing of the examination that is prepared by the Supreme Judicial Council; the age of the candidate must be above forty for the appointment of an appeals judge and above twentytwo for other ranks in the judiciary and finally the candidate must not be convicted of the impinging of religious crime or honor; the candidate should not be involved in the subject of disciplinary action that dismissed the candidate from public office, even for re-habitation. Examining the laws and rules followed by the judicial system in KSA, as previously asserted, Sharia Law is supreme and is the main source of legislation. Examples include the Civil Code and the Penal Code which are not codified and rely on the provisions of Islamic rules. However, the main procedural laws that govern the system are Code of Civil Procedures and the Code of Criminal Procedures. Unfortunately, most judges have extensive knowledge in Sharia Laws, yet are not familiar with the procedural laws, and thus such laws are not applied adequately to cases.

As for the courts, the Saudi judiciary system's act of establishing specialized courts is a remarkable step towards the development of the judicial institution because there will be a demand for specialized judges who are competent to resolve over disputes related to each of the different specialized branches. However, in 2016 the Personal Status Court, as well as the Commercial Court has been established yet Labor Courts were not. Therefore, judicial committees for the settlement of labor disputes have been established, which will be led by specialists in labor law and those who have certificates in law, to expedite the process of resolving labor cases. The problem lies in the fact that these committees are created and formed by the Ministry of Justice and thus lacks the most important feature of the judiciary, which is the independence and impartiality of the judges.

\section{b. The Legal Profession in KSA}

Law forms a profession that is still in the developmental phase in Saudi Arabia and does not impact the practice of courts. The procedures for lawyers in KSA were first issued in $2001 .^{20}$ Alkhalawi ${ }^{21}$ and $\mathrm{Karl}^{22}$ provide

\footnotetext{
${ }^{20}$ Alkhalawi, Op.Cit., p. 6
} 
insights into the different conditions that must necessarily be followed for practicing law in KSA. The most prominent requirement for this is the bachelor's degree in Sharia Law, where graduates would have extensive knowledge of Sharia and lack understanding of the new codified laws. This weakens the overall structure of law in KSA.

In 2015, the Council of Ministers in KSA issued a decree approving the establishment of the Saudi Bar Association. The Association aims to raise the level of practice of lawyers, to ensure their good performance and to increase their awareness of their professional duties. The authorities of the Association, as referred to in article 2, paragraph 2:

To achieve its objectives, the Association shall have all the necessary powers to do so, including the following:

1. Develop the rules and standards of practicing the profession, review and promote these standards according to the legal principles and applicable regulations;

2. Take care of the interests of the principal members of the Association related to practicing the profession according to the rules of the Charter, and work to provide them with the necessary services in this regard, including endorsement of their signatures;

3. Organize courses and hold conferences, seminars, meetings, forums and exhibitions related to the legal profession, as well as participating in them in coordination with the Ministry of Justice and according to the official procedures;

4. Develop and evaluate qualifying and training programs in the field of the profession, and participate in them with the competent authorities.

5. Conduct and publish studies and research, as well as publishing books, publications, scientific and professional journals and periodicals.

6. Submit proposals related to the profession to the competent authorities.

7. Provide legal aid and technical advice in the field of competence to the beneficiaries. ${ }^{23}$

This list shows that the authorities of the Association are focused on the development of the legal profession in Saudi Arabia and that this body was established based on the demands of lawyers themselves, but it does not enjoy independence regarding follow-up by the Ministry of Justice and the appointment of members. It would also be better to amend or abolish the

\footnotetext{
${ }^{21}$ Ibid.

${ }^{22}$ D. J. Karl, Op.Cit., p 6

${ }^{23}$ Saudi Bar Association Charter, April 27 2015, https://sba.gov.sa/en/saudi-bar-associationcharter/
} 
Saudi advocacy system and issue a new system that is updated by the recent legal development. The Saudi Lawyers' Association cannot issue the instructions or the regulations that conflict with the Saudi advocacy system, as it is considered supreme since a Royal Decree issued it.

\section{c. Teaching Law in KSA}

The first law department in Saudi Arabia was established in 1980 at King Saud University and was named as the Regulations Department. This department was formed as a part of the Faculty of Administrative Sciences. The department, however, was transformed into an independent college of law and political science in $2006 .{ }^{24}$ It started offering a bachelor's degree in law for both males and females. Another Regulation Department was later established at the King Abdul Aziz University in 1987 as a part of the Faculty of Management and Economics. This department offered bachelors in law degree as well. Similar to the former one, this department was also transformed into an independent college in 2012 and was specifically named as the Faculty of law. ${ }^{25}$ The past ten years have seen a tremendous increase in Saudi universities with law faculties. There have been 27 public universities located in different regions in the KSA. In addition to these, ten private universities have also been formed to offer law undergraduate programs. Law courses are also offered in some universities under the title of 'College of Sharia' and the Faculty of Business. It is important to note that it is only recently that the name of 'Faculty of Law' has been given to these departments since the majority of these are still acknowledged as Department of Regulations. This assumption is based on the fact that the inclusion of the term 'law' indicates for the human-made laws that sometimes are contrary to the Shariah provisions. ${ }^{26}$ Even though female lawyers are only rarely accepted in the Saudi Courts; the law education is available for both males and females.

In recent years, the study of the law has been increasingly targeted by students because of the market's need for qualified graduates, especially in private and the government sector. It has led universities in Saudi Arabia to increase law schools. Also, there are some universities in Saudi Arabia offering the law program in both Arabic and English. It contributes to providing the labor market with legal graduates who can work in both Arabic and English. This is what the labor market needs especially in Saudi

\footnotetext{
24 "King Saud University Bulletin Undergraduate Studies 1 - 2, Colleges of Humanitarian and Community Services, Retrieved from http://ksu.edu.sa/sites/AdminDepts/InfoStatistics/Our\%20Products/KSUBulletin_Undergradu ate1.pdf.

${ }^{25}$ Ibid.

${ }^{26}$ Alkhalawi, Op.Cit., p 7
} 
Arabia as it is witnessing the economic growth and therefore, the labor market needs legalists who master more than one language. In the legal profession, there is a negative impact on the work of law graduates because of the competition from graduates of Shariah colleges. Now, with the introduction of specialized commercial courts, this will increase the chances of law school graduates. If the judicial system is activated and specialized courts are established, the system will enhance the opportunities for law graduates. Due to the integrated system between the faculties of law, the judiciary, and the legal profession, all of them will lead to the development of the legal system in the Kingdom.

\section{d. Degree Plans of Law Programs in KSA}

The foundations of legal education in Saudi Arabia are entrenched in Jordan, Egypt, and France. The majority of the degree programs offered in KSA are similar to these countries based on the duration, the credit hours, and the nature of courses offered. Moreover, the Shariah courses offered aside from the other law courses vary based on the department/college, but must not exceed a total of $15 \% .{ }^{27}$ For instance, the fundamental courses of law taught in different departments include Shariah policies, family law, principles of jurisprudence, wills and inheritance, rules of jurisprudence, and zakat. Reviewing the law degrees offered in KSA, some drawbacks are evident. The problem can be found in criminal law and civil law courses. As mentioned previously, KSA does not codify these laws; therefore, Shariah is applied. However, law colleges offer certain courses that follow course plans of other countries that are heavily influenced by the Latin Legal System; for instance, Egypt and Jordan. Another challenge that is notable is the presence of Arab nationalities as teachers in KSA, who have received their law degrees in other jurisdictions and do not solely adhere to the Islamic laws. It significantly impacts the understanding and the comprehension of Shariah law among the students. ${ }^{28}$

It is very difficult to find a fully comprehensive degree plan under the current legal system in Saudi Arabia since the legal system depends on both the provisions of Islamic law as well as positive law, yet what curriculums usually lack is the inclusion of both laws. For example, civil laws are not codified in Saudi Arabia, and therefore the disputes relating to different rights are adjudicated according to the provisions of Islamic law. However, some laws are considered civil laws but are codified, such as the laws relating to the rights of ownership. Therefore, the student needs to study the civil laws according to Islamic law yet also to the positive law. The same

\footnotetext{
${ }^{27}$ Ibid.

${ }^{28}$ Ibid.
} 
goes for the criminal law since there is no written law on penalties in Saudi Arabia, the provisions of Islamic law is usually resorted to. There are, however, certain written laws regarding certain crimes such as the laws relating to fighting drugs and terrorism. As a certain number of hours governs the study plan, it is difficult to have a comprehensive plan for all legal and Islamic law subjects that would lead to the graduation of a student with full knowledge of both types of laws. If this is the case, the years of study will be at least six years, which is a practice that would differ from law schools in other countries of the world.

\section{Conclusion}

The findings of the research suggest that the integral problem that KSA encounters relative to the legal studies is the uniqueness of the Islamic system. Despite that it has a codified system of regulations, Shariah is still considered supreme. It has led to significant confusion in the Saudi system of education. It can be construed from the findings that comprehensive reforms to the legal system, the judicial system, and the legal structure are inevitable to develop the KSA's legal education. To resolve these challenges, the researcher makes the following recommendations: first, the legal provisions must be made explicit and clear so that they can be enforced to the written laws resulting in no violation of the Islamic provisions. The element of judges' discretion must be removed; they must not be allowed to decide between application of the Shariah and the written laws. Second, reforms should be made to KSA's judicial system. It can be supported based on the fact that the system was last updated ten years ago and the new judicial system has not yet been fully implemented particularly in regards to the development of the specialized courts. Third, the specialized courts' judges must hold a comprehensive knowledge of both the Shariah and the modern law to make the process more fluent and adequate. Fourth, regimens of legal practicing must be revised so that only the holders of legal certificates can enter the profession of law. Strengthened merit is created so that only the competent individuals can practice law. Individuals holding certificates in law must show sufficient familiarity with Shariah provisions. Contrarily, holders of the Shariah law must show adequate knowledge of the legal subjects essentially required to direct the criminal and civil law proceedings. Fifth, the educational curricula must be developed by the global advancement of legal education and to meet the requirements of both the local and the international community. Finally, teachers must not stick to the traditional Shariah, but this must be taught in light of the recent developments. 


\section{A. Book}

\section{Bibliography}

J. Carver \& M. Carver. (1996). Basic principles of policy governance, San Francisco, CA: Jossey-Bass.

Vogel, E. (2000). Islamic Law and the Legal System of Saudí: Studies of Saudi Arabia. Bril

\section{B. Journal and Paper}

A. Algarbouh, "The assessment of legal education in the Kingdom of Saudi Arabia," Proceedings of the Education and Learning Conference, Prince Sultan University, (2011).

A. H. Al-Fahad, "Ornamental constitutionalism: The basic Saudi law of governance," Yale Journal of International Law, 30 (2005).

A. Ehteshami, "Reform from above: the politics of participation in the oil monarchies," International Affairs, 79(1), (2003).

A.A. Al-Ghadyan, "The Judiciary in Saudi Arabia," Arab Law Quarterly, 13(3), (1998).

Brand, J. L. 'Aspects of Saudi Arabian Law and Practice'' Boston College International and Comparative Law Review, 9 (1), (1986).

D. J. Karl, "Islamic Law in Saudi Arabia: What Foreign Attorney's Should Know," George Washington Journal of International Law and Economics 25, (1991).

H. L. Stovall, "Arab Commercial Laws-Into the Future," The International Lawyer, 34(3), (2000).

L. Sossin, "Experience the Future of Legal Education," Alberta Law Review 51 (2013).

M. R. Grosu, "The Role of Innovative Teaching and Learning Methods in Legal Education," Proceedings of the International ConferenceFuture of Education, (Budapest, 2011)

M. Al Atawneh, "Is Saudi Arabia a theocracy? Religion and governance in contemporary Saudi Arabia", Middle Eastern Studies, 45(5), (2009).

R. A. Aldabas, "Special education in Saudi Arabia: History and areas for reform," Creative Education, 6(11), (2015).

R. Alkhalawi, Legal Education Reform in Saudi Arabia: A Case Study of Taibah University, Ph.D. dissertation, Maurer School of Law, Indiana University, Indiana, (2015).

S.Heikal, "Lawyering in Arab Countries between the Hammer of the Executive and the Anvil of the Judiciary," Journal of Studies in Social Sciences, 14(2), (2016). 


\section{World Wide Web}

"King Saud University Bulletin Undergraduate Studies $1-2$, Colleges of Humanitarian and Community Services, Retrieved from http://ksu.edu.sa/sites/AdminDepts/InfoStatistics/Our\%20Products/KS UBulletin_Undergraduate1.pdf.

Saudi Bar Association Charter, April 27 2015, https://sba.gov.sa/en/saudibar-association-charter/ 